\title{
The taxonomy and apparatus structure of the Silurian distomodontid conodont Coryssognathus Link \& Druce, 1972
}

\author{
C. GILES MILLER \\ Department of Geology \\ University of Leicester \\ Leicester LE1 7RH, UK
}

\author{
RICHARD J. ALDRIDGE \\ Department of Geology \\ University of Leicester \\ Leicester LE1 7RH, UK.
}

\begin{abstract}
Collections of discrete conodont elements from the Upper Whitcliffe Formation of the Welsh Borderland indicate a septimembrate plan for the feeding apparatus of Coryssognathus, comprising $\mathrm{Pa}, \mathrm{Pb}, \mathrm{Pc}, \mathrm{M}, \mathrm{Sa} / \mathrm{Sb}$, $\mathrm{Sb}$ and $\mathrm{Sc}$ elements. Each element is paired, and relative frequencies suggest that there was a total of 16 elements in the apparatus, including two indistinguishable pairs of Sc elements. Associated small coniform elements appear to represent discrete denticles of crown tissue that were sequentially incorporated into multidenticulate elements during ontogeny. J. Micropalaeontol. 12 (2): 241-255, December 1993.
\end{abstract}

\section{INTRODUCTION}

Conodonts are almost entirely known from the scattered elements of their apatitic feeding apparatuses. The multielement composition of these apparatuses can be partially or completely deduced through analyses of collections of discrete elements, but the only direct evidence of apparatus architecture comes from the rare occurrences of bedding-plane assemblages. These are preserved when individual conodonts died and decayed without any disturbance from currents, scavengers or infauna. Each bedding-plane assemblage comprises the complete apparatus of a single conodont, collapsed onto the bedding plane from its original three-dimensional geometry. Most bedding-plane assemblages are of Carboniferous age and represent just one conodont order, the ozarkodinids. These include the apparatuses preserved in the heads of the conodont animal specimens from the Granton Shrimp Bed, Edinburgh (Briggs et al., 1983; Aldridge et al., 1986, 1993). By studying the arrangement of assemblages preserved in different orientations it has been possible to reconstuct the three-dimensional architecture of ozarkodinid conodonts, with the ramiform $S$ and $M$ elements forming a basket in front of one pair each of $\mathrm{Pb}$ and $\mathrm{Pa}$ elements, both oriented perpendicular to the trunk of the animal (Aldridge et al., 1987). The apparatuses of representatives of all other conodont orders are much less well known, with the numbers and types of elements present often a matter of debate.

Conodonts were most diverse and variable in the Ordovician, but there is little direct evidence of the apparatus structure of most Ordovician taxa. The prioniodontid conodonts were one of the most characteristic groups, diminishing somewhat in the Silurian and becoming extinct by the latest Devonian or earliest Carboniferous (Sweet, 1988; Dzik, 1991; Aldridge \& Smith, 1993). Reconstructions based on collections of discrete elements have indicated that the prioniodontid feeding apparatus normally comprised six or seven different element types with the $P$ positions occupied by pastinate coniform or pectiniform elements or their platformed equivalents (Sweet, 1988). The only prioniodontid bedding-plane assemblages known are of the giant Upper Ordovician species Promissum pulchrum Kovács-Endrödy, and these display octomembrate apparatuses that differ considerably in architecture from the ozarkodinids (Theron et al., 1990). In particular, Promissum has three pairs of $P$ elements in contrast to the two of ozarkodinids, and the $M$ element is associated geometrically with the $P$ elements rather than the $S$ elements. In ozarkodinids, the $P$ elements are situated posterior to the set of ramiform $\mathrm{M}$ and $\mathrm{S}$ elements, whereas in Promissum they appear to have been positioned above or below (Theron et al., 1990; Aldridge \& Theron, 1993).

Not all prioniodontid taxa may conform to the Promissum plan, but the bedding-plane assemblages provide an initial template for reconstructing the apparatuses of other genera. For example, the suggestion that the Silurian genera Pterospathodus and Pranognathus had paired $\mathrm{Pa}, \mathrm{Pb}$ and $\mathrm{Pc}$ elements (Männik \& Aldridge, 1989) is consistent with the pattern shown by Promissum, although Pterospathodus appears to have had a reduced series of $S$ elements and lacks a truly symmetrical Sa element. Apart from the Pterospathodontidae, at least three other prioniodontid families are represented in the Silurian: the Distomodontidae, the Icriodellidae and the Icriodontidae, with rare Canadian specimens referred to "Apparatus A" by Uyeno (1981) perhaps representing the Rhipidognathidae (Aldridge \& Smith, 1993).

In this contribution, we provide a reconstruction of the apparatus of the late Silurian species Coryssognathus dubius (Rhodes), which serves as a guide to the apparatus structure 
of distomodontid conodonts. In Britain, this species first appears in the upper beds of the Upper Bringewood Formation of latest Gorstian age and spans the Ludfordian, with the highest record in the lowest beds of the Downton Castle Sandstone Formation (Aldridge, 1985; recorded as Distomodus? dubius and Pelekysgnathus dubius). The species is most abundant in the Upper Whitcliffe Formation (upper Ludfordian), and our investigation is primarily based on collections from this formation and its correlatives. The most complete reconstruction of the Coryssognathus apparatus published to date is that of van den Boogaard (1990), who recognised $\mathrm{Pa}, \mathrm{Pb}, \mathrm{M}, \mathrm{Sa}, \mathrm{Sb}, \mathrm{Sc}$ and coniform elements. Here, we distinguish $\mathrm{Pa}, \mathrm{Pb}, \mathrm{Pc}, \mathrm{M}, \mathrm{Sa} / \mathrm{Sb}, \mathrm{Sb}, \mathrm{Sc}$ and coniform elements, deduce the numbers of each in the apparatus and suggest a geometric configuration.

\section{SYSTEMATIC DESCRIPTION}

Phylum: Chordata Bateson, 1886

Class: Conodonta Pander, 1856

Order: Prionodontida Dzik, 1976

Family: Distomodontidae Klapper, 1981

Genus: Coryssognathus Link \& Druce, 1972

1980 ?Dentacodina Wang: 370

Type species. Cordylodus? dubius Rhodes, 1953, senior subjective synonym of Coryssognathus dentatus Link \& Druce, 1972.

Emended diagnosis. Apparatus septimembrate comprising $\mathrm{Pa}, \mathrm{Pb}, \mathrm{Pc}, \mathrm{M}, \mathrm{Sa} / \mathrm{Sb}, \mathrm{Sb}$ and Sc elements; each element paired with two indistinguishable pairs of Sc elements. $\mathrm{Pa}$ element scaphate, other elements robust with stout cusps and short processes. $\mathrm{Sa} / \mathrm{Sb}$ and $\mathrm{Sb}$ elements represent morphologically plastic symmetry transition series varying from nearly symmetrical to twisted and somewhat asymmetrical. $\mathrm{Pa}, \mathrm{Pb}, \mathrm{Pc}$ and $\mathrm{Sc}$ elements show crown lamellae sequentially enclosing denticles during ontogeny.

Remarks. Several generic names have been applied in the past to elements of the Coryssognathus apparatus. $\mathrm{Pa}$ elements of $C$. dubius were assigned to Pelekysgnathus Thomas, 1949, by Jeppsson (1972), a designation supported by Nicoll (1982) on the basis of associated coniform elements similar to those of other Pelekysgnathus species. However, it is clear that Coryssognathus Pa elements grew by successively incorporating neighbouring denticles (Jeppsson, 1972; van den Boogaard, 1990), in contrast with the Pa element of Pelekysgnathus, which has a posterior cusp and basal cavity tips only beneath the cusp and the immediately proximal denticle (van den Boogaard, 1990). A further distinction between the two genera lies in the rest of the apparatus, which in Pelekysgnathus is composed of coniform elements (Klapper \& Philip, 1972). The Sc element of Coryssognathus dubius was originally figured by Rhodes (1953) as Cordylodus? dubius, but the apparatus of the Lower Ordoxician genus Cordylodus is not comparable with that of Corysognathus (Sweet, 1988). The genera Distomodus Branson \& Branson, 1947, Rotundacodina Carls \& Gandl, 1969, and Dentacodina Wang, 1980, all include elements similar to those in the apparatus of $C$. dubius. Distomodus has a distinctive, multiprocessed Pa element, which, at least beyond the earliest juvenile stages, cannot be seen to have grown by successive incorporation of coniform elements. Elements referred by Carls \& Gandl (1969) to Rotundacodina appear to belong to species of the Devonian genus Icriodus, which has a distinctive Pa element (Serpagli, 1983). Dentacodina is a younger name than Coryssognathus and the nature of any $\mathrm{Pa}$ element associated with the specimens figured by Wang (1980) is unclear; a multidenticulate element identified as Pelekysgnathus of. index Klapper \& Murphy by Wang (1980, p. 374, pl. 2, figs 33-35) does occur in the same collections. The senior subjective synonym Astacoderma spinosum Harley has been suppressed by the International Commission on Zoological Nomenclature following a submission by Jeppsson \& Aldridge (1988).

Coryssognathus dubius (Rhodes, 1953)

1861 Astacoderma spinosum Harley: pl. 27, fig. 16a, b (Sc?).

1953 Distomodus suberectus Rhodes: 290, pl. 23, figs 207, 208 (Pb/Pc), 210, $211(\mathrm{M})$.

1953 Distomodus curvatus Rhodes: 290, pl. 23, figs 209, 226-228 $(\mathrm{Pb} / \mathrm{Pc})$.

1953 Distomodus curvatus var. dentatus Rhodes: 291, pl. 23, figs $217,218,229,230(\mathrm{~Pb} / \mathrm{Pc})$.

1953 Cordylodus? dubius Rhodes: 299, pl. 23, figs 221-224 (Sc).

1972 Distomodus dubius (Rhodes); Jeppsson: 56-58, pl. 1, figs 1 (M), 2-4 (Sc), 5 (Sa/Sb), 6 (Pb?), 7-9 (Pc), 10-13 (coniform).

1972 Pelekysgnathus dubius Jeppsson: 62-63, pl. 1, figs 14, 20, textfig. 5 (Pa).

1972 Coryssognathus dentatus Link \& Druce: 31-32, pl. 2, figs 13-19, text-fig. $13(\mathrm{~Pa})$.

1972 Cordylodus? dubius Rhodes; Link \& Druce: 30-31, pl. 2, figs 11, 12, text-fig. 12 (Sc).

1972 Distomodus curvatus Rhodes; Link \& Druce: 33-34, pl. 2, figs 20, $21(\mathrm{Pc}), 22,25$, text-fig. $15(\mathrm{~Pb})$.

1974 Gen et sp. indet. B Helfrich: pl. 12, figs 7, 8, 22 (Sc, Sc, Sa/Sb).

1974 Gen. et sp. indet. A Helfrich: pl. 12, fig. 26 (Sa/Sb)

1975 Distomodus dubius (Rhodes); Jeppsson: 18, pl. 1, figs 1 (Pb/Pc?), 2 (coniform), 3 (Sc), 4 (Sa/Sb), 5, 6 (Sc), pl. 2, fig. 1 (M).

1975 Pelekysgnathus dubius Jeppsson; Jeppsson: pl. 2, fig. 2a-c (Pa). 1975 Distomodus dubius (Rhodes); Aldridge: pl. 1, figs 10 (Sc), 11 (M), 12 (Sb), 13 (Pb), 14 (Sa/Sb).

1975 Pelekysgnathus dubius Jeppsson; Aldridge: pl. 1, figs 5-7 (Pa). 1978 Distomodus dubius (Rhodes); Pickett: pl. 1, figs 10, 13 (Pb/Pc), 11,12 (M), 14 (?Sa/Sb), 15-17 (Sc).

1979a Distomodus dubius (Rhodes); Jeppsson: fig. 1A (coniform), $4 \mathrm{~A}$ (Sa/Sb).

?1980 Dentacodina multidentata Wang: 370, pl. 1, figs 4, 7-10, 13 (Sc). ?1980 Dentacodina dubia (Rhodes); Wang: 370, pl. 2, figs 1, 2 $(\mathrm{Sa} / \mathrm{Sb})$.

?1980 Dentacodina trilinearis Wang: 370, pl. 2, figs 29, 30 (Sb?).

1985 Distomodus? dubius (Rhodes); Aldridge: pl. 3.4, figs 10 (Pb/Pc), 11 (M), 12 (Sc), 13 (Sa/Sb), 14 (Sb).

1985 Pelekysgnathus dubius Jeppsson; Aldridge: pl.3.4, fig. 16 (Pa). ?1989 Dentacodina trilinearis Wang; Walliser \& Wang: pl. 2, figs 17 (Sc), 18 (Sa/Sb), 26 (Sa/Sb), 27, 28 (Sc).

1990 Coryssognathus dentatus Link \& Druce; van den Boogaard: pl. 1, figs 1-7, pl. 2, figs 1, 2 (Pa).

1990 Coryssognathus dubius (Jeppsson); van den Boogaard: pl. 3, figs 3, 4, pl. 7, figs $2,3(\mathrm{~Pa})$. 


\begin{tabular}{|c|c|c|c|c|c|c|c|c|c|c|}
\hline Sample no. & $\overline{P a}$ & $P b / P C$ & $\bar{M}$ & $\begin{array}{c}S a / S b \\
(a)\end{array}$ & $\begin{array}{c}S a / S b \\
(b)\end{array}$ & $\begin{array}{c}S a / S b \\
(c)\end{array}$ & $\overline{S b}$ & $S c$ & $\begin{array}{l}\text { Coni } \\
\text { forms }\end{array}$ & $\begin{array}{c}\text { non } \\
\text { idents. }\end{array}$ \\
\hline $\begin{array}{l}5 \mathrm{c} 1 \\
5 \mathrm{c} 2\end{array}$ & 15 & $\begin{array}{c}32 \\
1\end{array}$ & 28 & $\begin{array}{c}10 \\
1\end{array}$ & 1 & 9 & $\begin{array}{l}8 \\
1\end{array}$ & $\begin{array}{c}21 \\
1\end{array}$ & 20 & 4 \\
\hline 6 & & 4 & 1 & & & & & 1 & & 1 \\
\hline $39 / 1^{*}$ & 15 & 58 & 30 & 5 & 3 & 18 & 17 & 50 & 24 & 7 \\
\hline $7 \mathrm{a} 4$ & 8 & 4 & 5 & 3 & 1 & 3 & 1 & 7 & & 2 \\
\hline $7 a 5$ & 1 & 7 & 1 & 2 & & 7 & & 6 & & 3 \\
\hline $38 / 1 *$ & 10 & 27 & 9 & 2 & 3 & 8 & 13 & 29 & 12 & 8 \\
\hline 8 & & 11 & 3 & & 2 & 2 & 1 & 4 & 6 & 1 \\
\hline 10 & & 1 & 1 & & & & 2 & 2 & & \\
\hline $14 b 3$ & l & 9 & 5 & & & 5 & 1 & 10 & 1 & 2 \\
\hline $14 c$ & 4 & س & $\frac{12}{3}$ & 2 & 5 & س & & 10 & & \\
\hline $\begin{array}{c}73 / 1 * \\
15 \mathrm{a} 2\end{array}$ & $\begin{array}{l}1 \\
3\end{array}$ & $\begin{array}{c}3 \\
21\end{array}$ & 9 & 1 & 1 & 4 & 3 & 6 & 5 & 2 \\
\hline $15 b 1$ & & 1 & & 2 & 5 & 3 & 11 & 24 & 18 & 7 \\
\hline $\begin{array}{c}74 / 1 * \\
15 \mathrm{c} 1\end{array}$ & $\begin{array}{c}12 \\
1\end{array}$ & $\begin{array}{c}37 \\
1\end{array}$ & 21 & 2 & 5 & 3 & 11 & 1 & 1 & \\
\hline $15 \mathrm{c} 2$ & 5 & 18 & 16 & 1 & 1 & 2 & 8 & 13 & 4 & 2 \\
\hline $15 \mathrm{~d} 1$ & 3 & 12 & 3 & 2 & 1 & 1 & 3 & 4 & 5 & \\
\hline $75 / 1^{*}$ & 1 & & & & & & & 1 & 2 & \\
\hline $76 / 1 *$ & & 5 & i & & & 2 & 1 & 2 & & \\
\hline $\begin{array}{l}77 / 2 * \\
17 \mathrm{as} \\
17 \mathrm{~b} 4\end{array}$ & 3 & 9 & 11 & 2 & 1 & $\begin{array}{l}3 \\
1 \\
1\end{array}$ & 3 & 18 & 14 & 5 \\
\hline $\begin{array}{l}18 / 1 \\
18 / 4\end{array}$ & 13 & 31 & 36 & 4 & 3 & $\begin{array}{l}7 \\
2\end{array}$ & $\begin{array}{l}4 \\
1\end{array}$ & 27 & 27 & $\begin{array}{c}44 \\
1\end{array}$ \\
\hline $20 / 1 \mathrm{a}$ & & 7 & 8 & & 3 & 3 & 7 & 14 & 29 & \\
\hline $20 / 1 b$ & & 7 & 4 & & 1 & 3 & & 9 & 25 & \\
\hline $115 / 1 *$ & 17 & 116 & 73 & 5 & 20 & 38 & 30 & 116 & 225 & 12 \\
\hline $\begin{array}{l}20 / 2 \\
20 / 4\end{array}$ & 1 & & 2 & & & 3 & 2 & 1 & & 1 \\
\hline 22 & 1 & 13 & 13 & 1 & & 4 & 6 & 7 & 38 & 2 \\
\hline $160 / 1^{*}$ & 4 & 17 & 14 & 2 & & 8 & 7 & 21 & 52 & 2 \\
\hline $23 \mathrm{a} 3$ & 1 & 4 & 4 & 2 & & 3 & 1 & 6 & & 3 \\
\hline $23 \mathrm{~b} 1$ & 4 & 3 & 6 & & & 2 & 3 & 8 & 10 & \\
\hline $161 / 1 *$ & 5 & 44 & 39 & 5 & 6 & 17 & 26 & 92 & 201 & 4 \\
\hline $24 a 1 a$ & & 2 & 5 & & 2 & 2 & & 2 & 9 & \\
\hline $162 / 1^{*}$ & & 3 & 1 & 1 & & & & 2 & 1 & 1 \\
\hline $24 a 2 a$ & & 40 & 12 & 4 & 14 & 10 & 16 & 42 & 119 & 7 \\
\hline $162 / 2 *$ & 11 & 70 & 52 & 4 & 4 & 14 & 56 & 80 & 158 & 2 \\
\hline $24 \mathrm{a} 3$ & 7 & 75 & 37 & 11 & 9 & 19 & 27 & 63 & 61 & 24 \\
\hline $24 \mathrm{a} 4$ & & 26 & 10 & 1 & 4 & 7 & 10 & 35 & 112 & 5 \\
\hline $162 / 3^{*}$ & & 1 & & & & & 1 & & 3 & 1 \\
\hline$\frac{24 a 8}{24 b 1}$ & 2 & 3 & 1 & 1 & 1 & 3 & 3. & 7 & 1 & \\
\hline $\begin{array}{l}24 \mathrm{~b} 2 \\
24 \mathrm{~b} 3\end{array}$ & 4 & $\begin{array}{c}1 \\
22\end{array}$ & 18 & 8 & 4 & 11 & $\begin{array}{l}3 \\
5\end{array}$ & $\begin{array}{c}2 \\
17 \\
2\end{array}$ & 3 & $\begin{array}{l}1 \\
7\end{array}$ \\
\hline $31 / 1$ & 16 & 45 & 32 & 7 & 1 & 14 & 12 & 38 & 21 & 20 \\
\hline $31 / 2$ & 3 & 2. & 9 & 1 & 2 & 5 & 2 & 4 & & \\
\hline $31 / 3$ & 35 & 53 & 40 & 11 & & 11 & 12 & 37 & 8 & 8 \\
\hline $31 / 4$ & 24 & 45 & 27 & 8 & 1 & 17 & 4 & 56 & 37 & 32 \\
\hline $31 / 5$ & 2 & 19 & 35 & 5 & 4 & 21 & 11 & 34 & 5 & 38 \\
\hline $31 / 6$ & & 9 & 6 & 1 & 2 & 3 & 1 & 5 & 15 & 7 \\
\hline $31 / 7$ & & 1 & 7 & 2 & & & & & 10 & 3 \\
\hline $31 / 8$ & & & 1 & & & 3 & & 1 & & 2 \\
\hline $33 / 1$ & 9 & 34 & 26 & 7 & l & 3 & 5 & 19 & 7 & 32 \\
\hline $33 / 2$ & 6 & 10 & 24 & 3 & 2 & 3 & 5 & 17 & 10 & 23 \\
\hline $33 / 3$ & 10 & 31 & 15 & 6 & & 2 & 8 & 24 & 11 & 10 \\
\hline $\begin{array}{l}33 / 4 \\
33 / 5\end{array}$ & 6 & $\begin{array}{c}11 \\
1\end{array}$ & $\begin{array}{l}2 \\
1\end{array}$ & 2 & 1 & & 1 & 2 & 5 & 3 \\
\hline $36 \mathrm{a} / \mathrm{k}$ & 1 & 6 & 1 & & & & & & & 2 \\
\hline $39 a 1$ & & 2 & 1 & & I & & 2 & 4 & & 8 \\
\hline $43 / 1$ & 4 & 15 & 5 & 1 & & 7 & 8 & 13 & 6 & 3 \\
\hline TOTAL & 269 & 1046 & 726 & 136 & 110 & 323 & 362 & 1009 & 1323 & 358 \\
\hline$\%$ & 7 & 26 & 18 & 4 & 3 & 8 & 9 & 25 & - & - \\
\hline
\end{tabular}

Fig. 1. Frequencies of elements from the apparatus of C. dubius from the Upper Whitcliffe Formation and lowermost Downton Castle Sandstone Formation of the Welsh Borderland. Localities as listed in text. 
1990 Distomodus dubius (Rhodes); van den Boogaard: pl. 3 , figs 1, 2 (M), 5 (Pb/Pc?), pl. 4, figs 1, 2 (Pc), 3, 4 (Sc), 5, 6 $(\mathrm{Sa} / \mathrm{Sb}), 7(\mathrm{M}), 8,9(\mathrm{Sa} / \mathrm{Sb}), 10(\mathrm{~Pb}), 11(\mathrm{~Pb} / \mathrm{Pc}$ ) $)$ pl. 5, figs 1 (M), 2 (Pb/Pc), pl. 7, fig. 1 (Pc).

Diagnosis. Pa element with erect triangular cusp, denticulate inner lateral process well developed in mature specimens. $\mathrm{Pb}$ and $\mathrm{Pc}$ elements with triangular bases. $\mathrm{Sa} / \mathrm{Sb}$ and $\mathrm{Sb}$ elements with strongly curved cusps and weakly developed peg-like denticles on posterior process. Sc element with up to four denticles on posterior process.

Holotype. School of Earth Sciences, University of Birmingham, UK., No. CIIE2a. Figured by Rhodes, 1953, pl. 23, figs 221-223, from the Aymestry Limestone of Shropshire.

Material. 5,868 elements (269 Pa, $1046 \mathrm{~Pb} / \mathrm{Pc}, 726 \mathrm{M}, 565$ Sa/Sb, 362 Sb, 1009 Sc, 1323 coniform elements, 358 not assignable). Repository of figured specimens: Natural History Museum, London.

Localities and horizons. C. dubius has been reported by Jeppsson $(1972,1975,1979 b, 1984)$ from the Ludlow of Skanne and Gotland, by Link \& Druce (1972) from the Ludlow of the Yass Basin, Australia, by Helfrich (1974) from the Wills Creek Formation of Virginia, U.S.A, by Harley (1861), Rhodes (1953) and Aldridge $(1975,1985)$ from the Upper Bringewood Formation to Downton Castle Sandstone Formation of the Welsh Borderland, by Wang (1980) from the upper Silurian of the Qujing District, Junnan, China, by Viira (1982) from the upper part of the Paadla Stage of Estonia, and by van den Boogaard (1990) from the Ludlow of Irian Jaya, Indonesia.

Samples examined in this study are from the Upper Whitcliffe Formation and its lateral equivalents, Ludlow Series of Wales and the Welsh Borderland, unless stated. The locality and sample numbers are those used by Miller (1993):

Loc. 5c. Brockton, Corve Dale, Shropshire, GR SO 57659400. Upper Whitcliffe Formation; (sample numbers 5c1, 5c2).

Loc. 6c. Shipton, Corve Dale, Shropshire, GR SO 56349186. Upper Whitcliffe Formation; (6c).

Loc. 7a. Aston Munslow, Corve Dale, Shropshire, GR SO 5124 8658. Upper Whitcliffe Formation; (39/1, 7a4, 7a5).

Loc. $7 \mathrm{~b}$. Aston Munslow, Corve Dale, Shropshire, GR SO 5113 8671. Upper Whitcliffe Formation; (38/1).

Loc. 8. Diddlebury, Corve Dale, Shropshire, GR SO 503858. Upper Whitcliffe Formation; (8).

Loc. 10. Siefton, Corve Dale, Shropshire, GR SO 47708475. Upper Whitcliffe Formation; (10).
Loc. 14b. Weir Quarry, Downton, Shropshire, GR SO 4560 7525. Downton Castle Sandstone Formation (Prídolí); (14b3).

Loc. 14c. Downton Castle Bridge, Downton, Shropshire, GR SO 4442 7402. Downton Castle Sandstone Formation (Prídolí); (14c).

Locs 15a-d. Whitcliffe Quarry Ludlow, Shropshire, GR SO 5098 7414. Lower and Upper Whitcliffe formations; (73/1, 15a2, 15b1, 74/1, 15c1, 15c2, 15d1, 75/1).

Loc. 16. Charlton Arms car park, Ludlow, Shropshire, GR SO 5116 7416. Upper Whitcliffe Formation; (16).

Loc. 17a, b. Ludford Lane, Ludlow, Shropshire, GR SO 5116 7413. Upper Whitcliffe Formation and Downton Castle Sandstone Formation (Pridoli); (77/2, 17a5, 17b4)

Loc. 18. Ludford Corner, Ludlow, Shropshire, GR SO 5124 7413. Upper Whitcliffe Formation and Downton Castle Sandstone Formation (Prídoli); $(18 / 1,18 / 4)$.

Loc. 20. Tramway cutting, Salt Wells Nature Reserve, Netherton, Dudley, West Midlands, GR SO 93588732. Upper Whitcliffe Formation; $(20 / 1 \mathrm{a}, 20 / 1 \mathrm{~b}, 115 / 1,20 / 2$, 20/4).

Loc. 22. Brockhill Quarry, Malvern Wells, Hereford \& Worcester, GR SO 7568 4394. Whitcliffe Flags Member, Upper Ludlow Formation of Phipps and Reeve (1967); (22).

Loc. 23a, b. Perton Lane near Woolhope, Hereford \& Worcester, GR SO 5791 4035. Upper Perton Beds of Squirrell \& Tucker (1960); (160/1, 23a3, 23b1, 161/1)

Loc. 24a. Prior's Frome near Woolhope, Hereford \& Worcester, GR SO 5662 3901. Upper Perton Beds of Squirrell \& Tucker (1960); (24a1a, 162/1, 24a2a, 162/2, 24a3, 24a4, $162 / 3,24 a 8)$.

Loc. 24b. Prior's Frome near Woolhope, Hereford \& Worcester, GR SO 5662 3901. Rushall Beds (Prídolí) of Squirrell \& Tucker (1960); (24b1-24b3).

Loc. 31. Tite's Point, foreshore of Severn Estuary, Purton, Gloucestershire, GR SO 688 046. Whitcliffe Beds of Cave \& White (1971); (31/1-31/8).

Loc. 33. Brook House, Usk, Gwent, GR SN 356 957. Upper Llangibby Beds of Walmsley (1959); (33/1-33/5).

Loc. 36a. Wallop Hall, Long Mountain near Welshpool, Powys, GR SJ 3150 0725. Upper metre of Causemountain Formation of Palmer (1970); (36a/k).

Loc. 39a. Forestry cutting, Clun Forest, Shropshire, GR SO 317 836. Platyschisma helicites Beds (Prídolí) of Earp (1938); (39a1).

Loc. 43. Capel Horeb Quarry, Llandovery, GR SN 84453234. Long Quarry Beds (Prídolí) of Potter \& Price (1965); (43/1).

\section{Explanation for Plate 1}

Figs 1-14. Coryssognathus dubius (Rhodes, 1953), Pa elements from the Upper Whitcliffe Formation. Figs 1, 2. PM X 1210, sample 115/1, Tramway cutting, Netherton, West Midlands (loc. 20), X50: Fig. 1. Stereo pair, oral view; Fig. 2. Lateral. Figs 3, 4. PM X 1285, sample 31b/3, Foreshore to Severn Estuary, Tite's Point, Gloucestershire (loc. 31b), X38: Fig. 3. Stereo pair, oral view; Fig. 4. Lateral. Figs 5, 6. PM X 1209, sample and locality as for fig. 1, X58: Fig. 5. Stereo pair, oral view; Fig. 6. Lateral. Figs 7, 8. PM X 1232, sample 160/1, Perton Lane, Perton, Hereford and Worcester (loc. 23a), X34: Fig. 7. Stereo pair, oral view; Fig. 8. Lateral.

Figs 9, 10. PM X 1161, sample 7a/4, opposite Swan Inn, Aston Munslow, Corve Dale, Shropshire (loc. 7a), X34: Fig. 9. Lateral; Fig. 10. Stereo pair, oral view. Figs 11, 12. PM X 1162, sample 39/1, locality as for fig. 9, X34: Fig. 11. Lateral; Fig. 12. Stereo pair, oral view Figs 13, 14. PM X 1159, horizon and locality as for fig. 9, X34: Fig. 13. Stereo pair, oral view; Fig. 14. Lateral. 


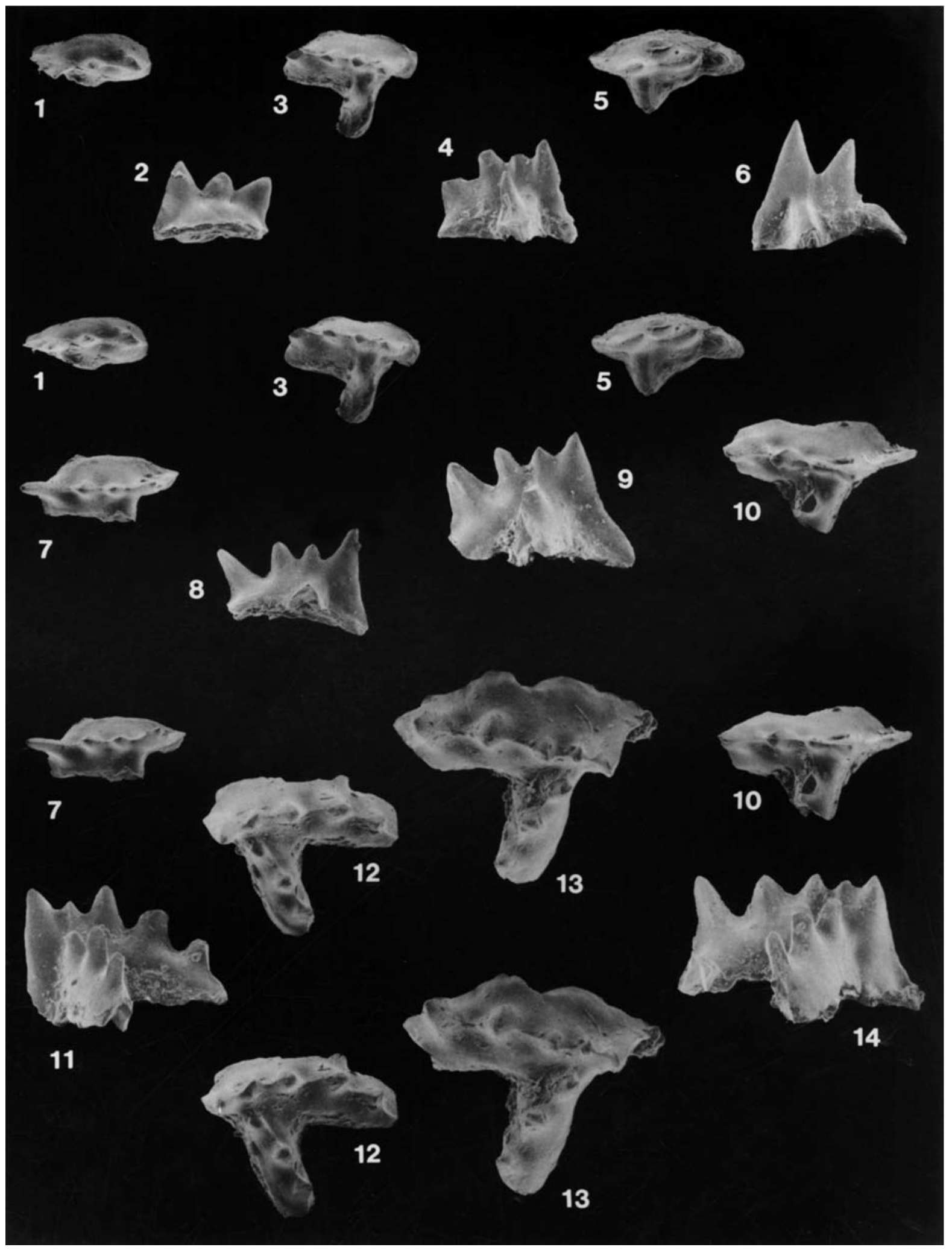




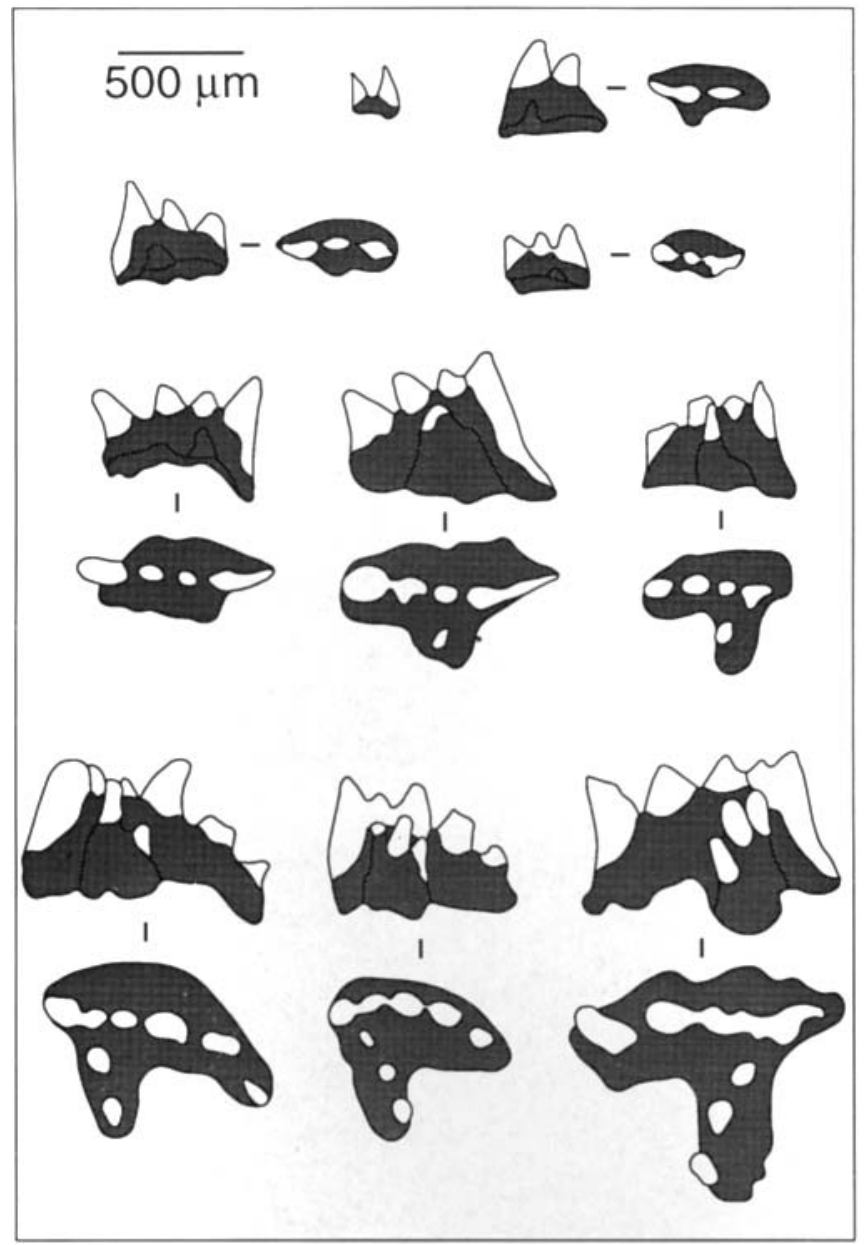

Fig. 2. Pa elements of $C$. dubius showing ontogenetic changes in morphology. Elements shown in inner lateral and oral views, specimen numbers from top left: PM X 1224, PM X 1209, PM X 1225, PM $X 1210, P M X 1232, P M X 1161, P M X 1285, P M X$ 1284, PM X 1162, PM X 1159.

Description. Pa element (Fig. 2 and Pl. 1, figs 1-14): scaphate, with anterior, erect cusp, which is not markedly larger than other denticles. Posterior process with one to four compressed, triangular denticles, inclined to posterior; distal denticle often largest. Denticles may be partially fused, and proximal denticle may be fused to cusp (Pl. 1, fig. 9). All denticles lenticular in section, those closest to cusp smooth, posteriormost denticles in mature specimens often with small longitudinal ridge on inner and outer lateral faces. Anterior process adenticulate, weakly developed as extension to ridge on anterior side of cusp. Lateral process of juvenile specimens present only as fold on inner lateral surface; mature specimens have welldeveloped posteriorly curved process arising immediately posterior of cusp and bearing one to three denticles (Pl. 1, figs 3, 4, 9-14); denticles similar to those on posterior process. Basal cavity deepest at junction of posterior and lateral processes; thick layer of spongelike basal body up to $80 \mu \mathrm{m}$ thick present in all specimens. Cavity extends under entire element. White matter clearly defines denticles and characteristically extends downwards almost to termination of anterior process (Fig. 2).

$P b$ and $P_{C}$ elements (Fig. 3 and Pl. 2, figs 1-15): the morphological terminology of Jeppsson (1972, p. 57) is used in this description. Each element pastinate with weakly developed processes. Cusp tall, prominent, displaying sharp postero-lateral and inner antero-lateral edges; inner face between lateral edges proximally falcoid to weakly biconcave, outer face strongly convex. Cusp twisted, becoming lenticular distally, so that posterior lateral edge migrates into lateral position. Short processes arise from sharp edges; those of Pc element more strongly developed than $\mathrm{Pb}$ element. Base hyaline, with distinct transition to white matter of cusp; denticles also albid when present.

$\mathrm{Pb}$ element (Pl. 2, figs 1-6): with three weakly developed, simple processes. Inner antero-lateral process with single triangular denticle showing distinct suture at base and occasionally barely attached to element (P1. 2, fig. 3). Postero-lateral process rarely develops small stubby denticle fused to inner base of cusp. Outer antero-lateral process adenticulate and only visible proximally, blending into strongly convex outer face distally.

$P c$ element (P1. 2, figs 7-15): with inner antero-lateral process better developed than outer antero-lateral and postero-lateral processes. Inner antero-lateral process adenticulate or with up to three denticles of lenticular cross section and circular bases; distal denticle normally best developed. Stubby triangular denticle on posterior lateral

\section{Explanation for Plate 2}

Figs 1-18. Coryssognathus dubius (Rhodes, 1953), $\mathrm{Pb}, \mathrm{Pc}$ and $\mathrm{M}$ elements, Upper Whitcliffe Formation. Figs 1, 2. Pb element, PM X 1243, sample 24a/2a, Prior's Frome, Hereford and Worcester (loc. 24a): Fig. 1. Lateral, X 60; Fig. 2. Detail of base, X180. Figs 3, 4. Pb element, PM X 1203, sample 115/1, Tramway cutting, Netherton, West Midlands (loc. 20): Fig. 3. Lateral stereo pair, X 70; Fig. 4. Detail of denticle on inner anterior lateral process, X525. Figs 5, 6. Pb element, PM X 1283, sample 31b/4, foreshore of Severn Estuary, Tite's Point, Gloucestershire (loc. 31b): Fig. 5. Aboral showing basal body, X90; Fig. 6. Lateral, X45. Figs 7-9. Pc element, PM X 1205, sample 115/1, locality as for fig. 3: Fig. 7. Lateral stereo pair, X130; Fig. 8. Aboral, X150; Fig. 9. Detail of cavity under outer anterior process showing lamellae enclosing denticle, X320. Figs 10, 11. Pc element, PM X 1204, sample and locality as for fig. 7: Fig. 10. Lateral, X100; Fig. 11. Aboral, X190. Figs. 12-14. Pc element, PM X 1282, sample and locality as for fig. 5: Fig. 12. Lateral, X42; Fig. 13. Detail of junction of denticle with basal body on inner anterior lateral process, X700; Fig. 14. Denticles on inner anterior lateral process, X100. Fig. 15. Pc element, lateral, PM X 1202, sample and locality as for fig. 3, X80. Fig. 16. M element, posterior, PM X 1242, sample and locality as for fig. 1, X62. Fig. 17. M element, posterior, PM X 1250, sample and locality as for fig. 1, X75. Fig. 18. M element, posterior, PM X 1208, sample and locality as for fig. 3, X100. 


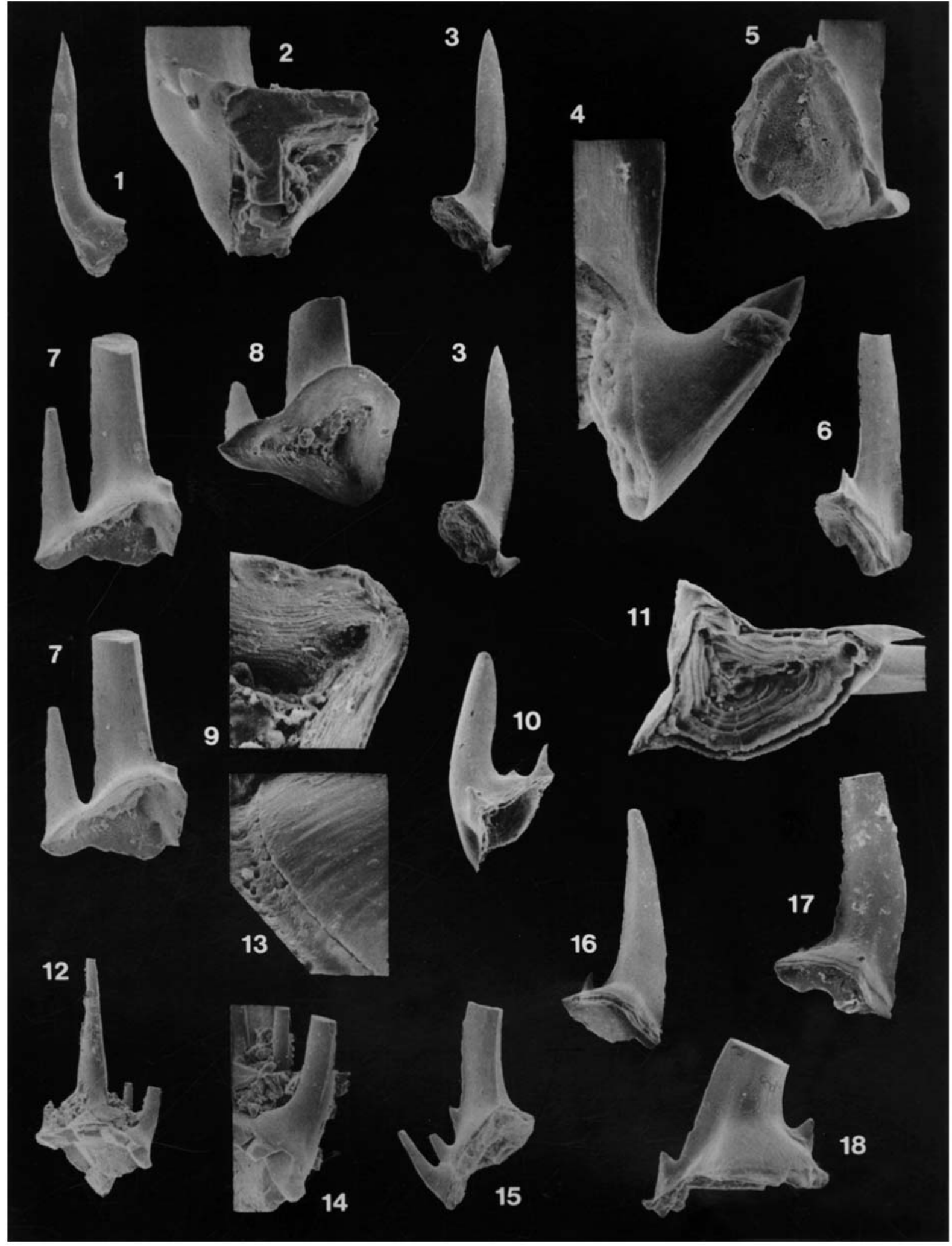




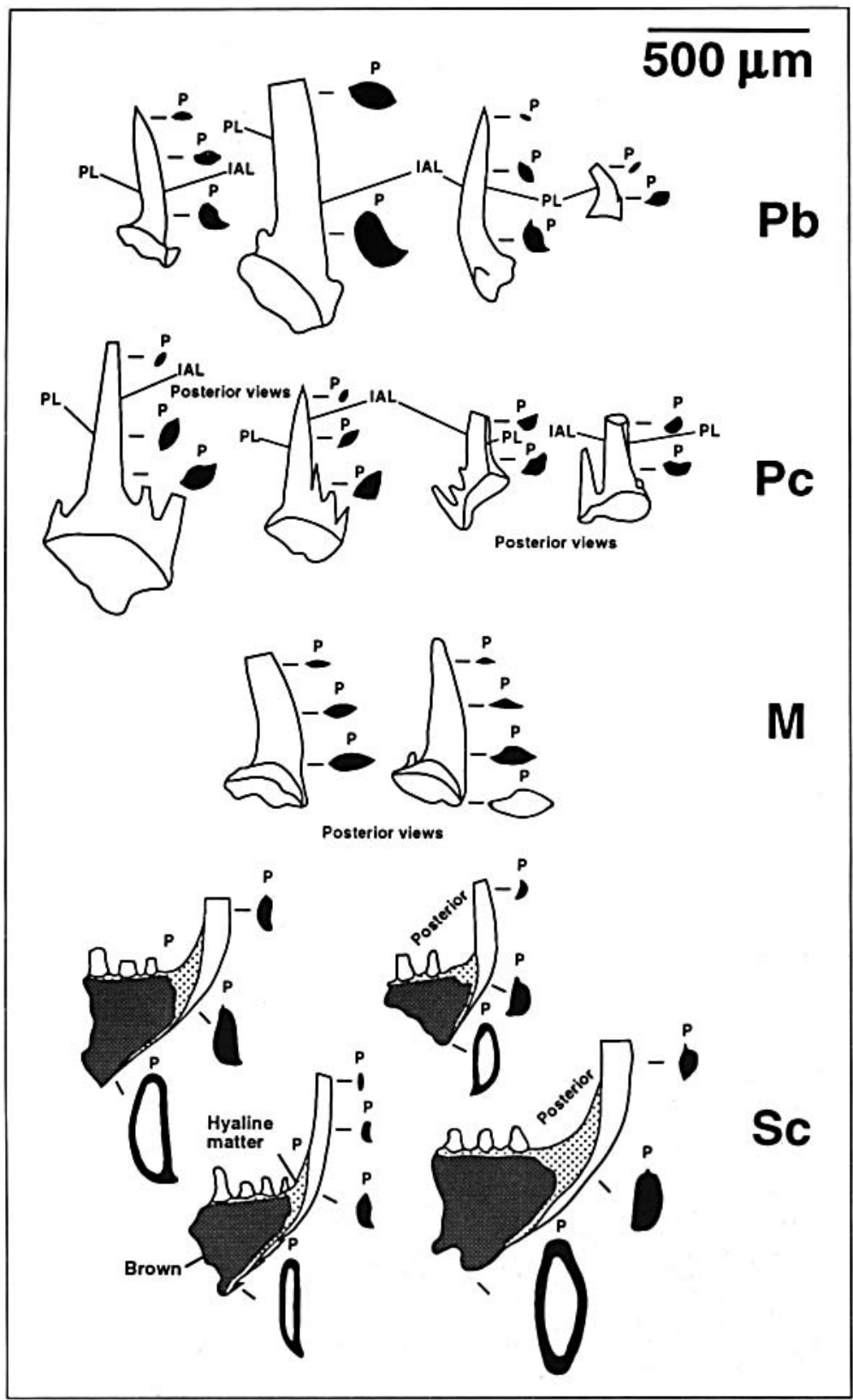

process blends into inner side of the cusp. Outer anterior process minor and adenticulate. Basal cavity triangular, margins when complete are convex between outer anterior and posterior lateral processes and concave either side of outer anterior lateral process (Pl. 2, fig. 11). Within basal cavity, each denticle has own basal pit with later lamellae enclosing each denticle (P1. 2, figs 9, 11); cavity commonly contains basal body.

$M$ element (Fig. 3 and Pl. 2, figs 16-18): makellate form. Cusp curved posteriorly and inwards, compressed, lenticular in cross section with sharp lateral edges. Proximally, posterior face of cusp more strongly convex than anterior which is almost flat in some specimens. Outer lateral part of posterior face striated. Outer lateral process very short, but more strongly developed than inner; bears small compressed denticle separate from margin. Inner lateral process rarely denticulate with denticle confluent with inner lateral margin (Pl. 2, fig. 18). Shallow lenticular basal cavity with posterior margin slightly pinched and anterior margin weakly convex (Fig. 3). Thickened area above cavity hyaline with a distinct transition to white matter of cusp and denticles.

Sa/Sb element (Fig. 4 and Pl. 3, figs 1-8): specimens show wide range of symmetry; morphotype A nearly symmetrical, morphotypes $B$ and $C$ increasingly asymmetrical; symmetry transition continuous, with intermediate forms between morphotypes common (Fig. 4). No truly symmetrical element distinguished.

Morphotype A (Fig. 4 and Pl. 3, figs 1, 2): tertiopedate, but nearly symmetrical, with three well developed costae on lower half of cusp. Cusp becomes lenticular distally with posterior and

Fig. 3. $\mathrm{Pb}, \mathrm{Pc}, \mathrm{M}$ and $\mathrm{Sc}$ elements from the apparatus of C. dubius. $\mathrm{P}=$ posterior, $\mathrm{PL}=$ posterio-lateral edge, $\mathrm{IAL}=$ inner anterio-lateral edge. Specimen numbers from top left: PM X 1203, PM X 1283, PM X 1243, PM X 1256, PM $X 1282, P M X 1253, P M X 1202, P M \times 1205$, $\mathrm{PM} \times 1250, \mathrm{PM} \times 1242, \mathrm{PM} \times 1249, \mathrm{PM} \times 1240, \mathrm{PM} X$ 1245, PM X 1248.

\section{Explanation for Plate 3}

Figs 1-12. Coryssognathus dubius (Rhodes, 1953), symmetry transition series, Upper Whitcliffe Formation, all specimens illustrated from the posterior. Fig. 1. Sa/Sb element, morphotype A, PM X 1255, sample 24a/2a, Prior's Frome, Hereford and Worcester (loc. 24a), X100. Fig. 2. Sa/Sb element, morphotype A, stereo pair, PM X 1179, sample 15c/1, Whitcliffe Quarry, Ludlow, Shropshire (loc. 15c), X60. Fig. 3. Sa/Sb element, morphotype B, PM X 1201, sample 115/1, Tramway cutting, Netherton, West Midlands (loc. 20 ), X60. Fig. 4. Sa/Sb element, morphotype B, PM X 1251, sample and locality as for fig. 1, X55. Fig. 5. Sa/Sb element, morphotype B, stereo pair, PM X 1239, sample and locality as for fig, 1, X70. Fig. 6. Sa/Sb element, morphotype C, stereo pair, PM X 1207, sample and locality as for fig. 3, X60. Fig. 7. Sa/Sb element, morphotype C, PM X 1230, sample 22/1, Brockhill Quarry, near Malvern Wells, Hereford and Worcester (loc. 22), X70. Fig. 8. Sa/Sb element, morphotype C, PM X 1281, sample 31b/3, foreshore of Severn Estuary, Tite's Point, Gloucestershire (loc. 31b), X120. Fig. 9. Sb element, PM X 1228, sample and locality as for fig. 7, X60. Fig. 10. Sb element, PM X 1271, sample and locality as for fig. 1, X45. Fig. 11. Sb element, PM X 1255, sample and locality as for fig. 1, X60. Fig. 12. Sb element, stereo pair, PM X 1252, sample and locality as for fig. 1, X60. 


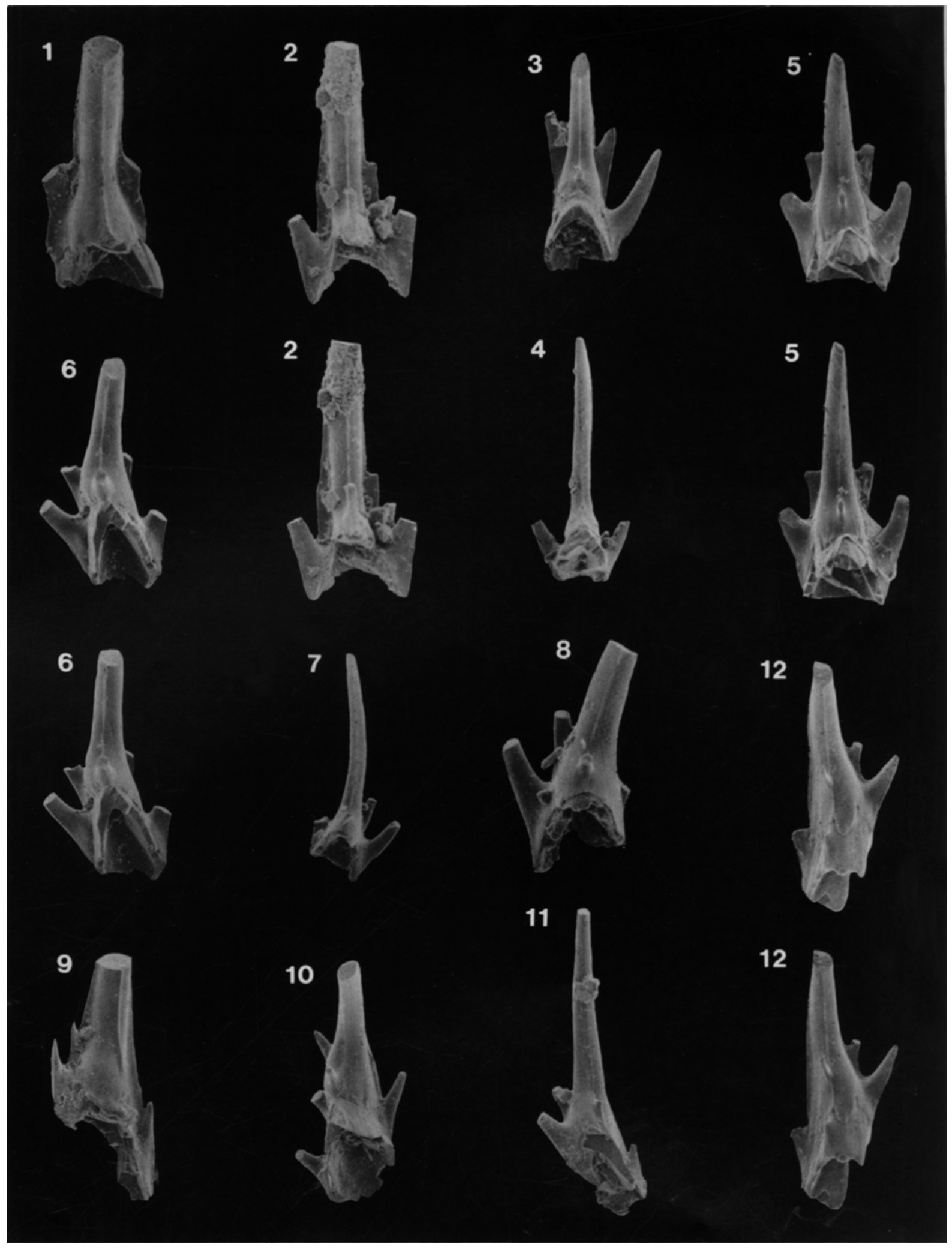




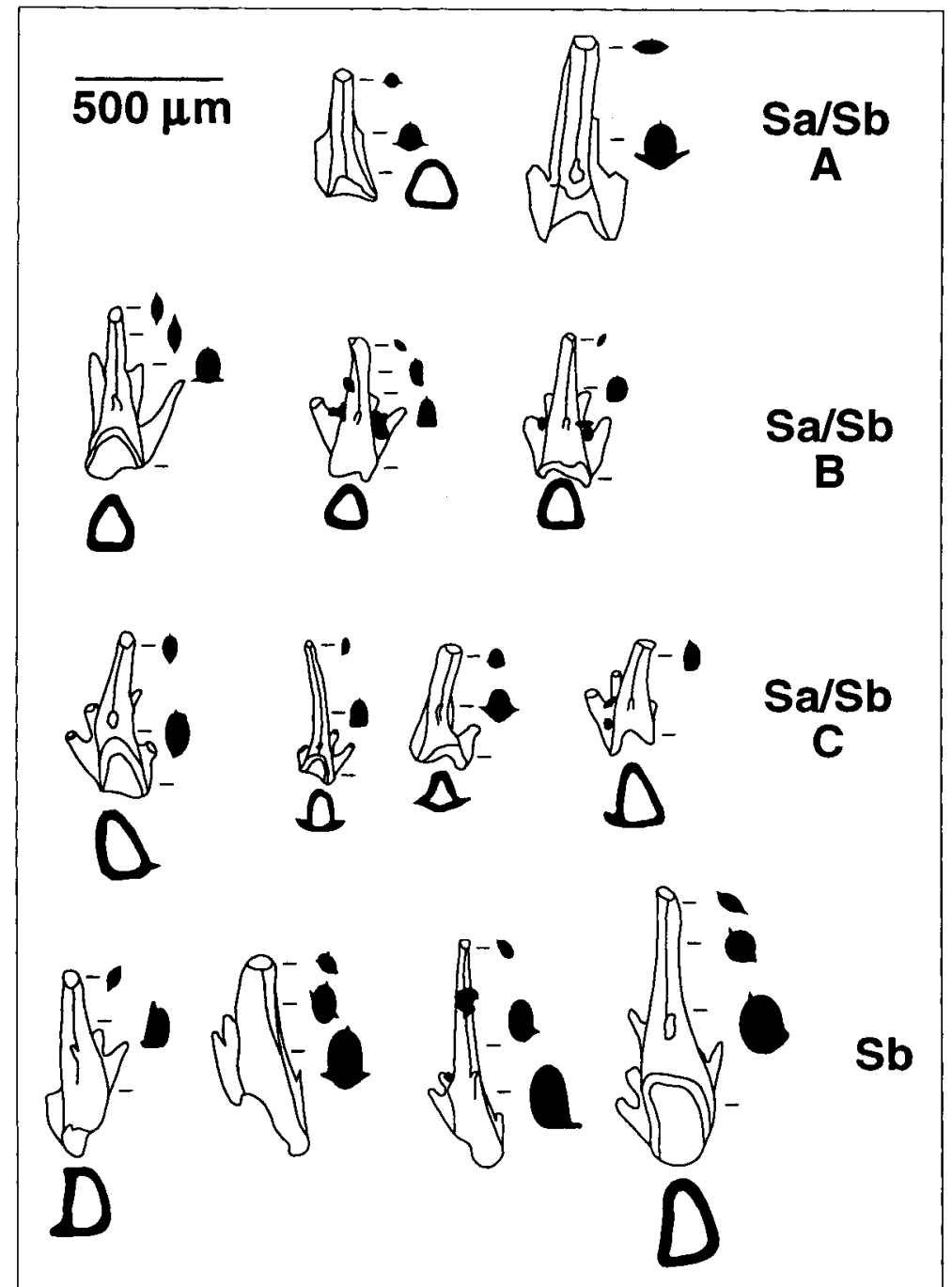

Fig. 4. Symmetry transition in $\mathrm{Sa} / \mathrm{Sb}$ and $\mathrm{Sb}$ elements from the apparatus of $C$. dubius. All elements are drawn from the posterior and cross sections of the elements are drawn with the posterior facing the top of the page. Specimen numbers from top left: PM X 1255, PM X 1179, PM X 1201, PM X 1251, PM X 1239, PM X 1207, PM X 1230, PM X 1229, PM X 1281, PM X 1252, $\mathrm{PM} \times 1228, \mathrm{PM} \times 1255, \mathrm{PM} \times 1271$ anterior faces flattened; single costa on posterior face. Lateral costae confluent with short, downwardly and outwardly directed processes, each bearing a single appressed denticle with its base at cavity margin; processes may be accentuated by breakage of part of cavity lips (P1. 3, fig. 2). Posterior process at base of cusp, short with peg-like denticle extending axially from costa on the posterior face of the cusp. Base hyaline; cusp, denticles, costae and posterior process composed of distinct white matter.

Morphotype B (Fig. 4 and Pl. 3, figs 3-5): tertiopedate with cusp slightly twisted and denticles sub-symmetrically arranged either side of cavity. Well developed costa on posterior face of cusp extends from base to tip and may be twisted sinistrally (Pl. 3, fig. 4) or dextrally (Pl. 3, fig. 5). Cusp triangular at base with convex lateral faces, becoming lenticular towards tip (Fig. 4). Small posterior process with peg-like denticle developed at base of posterior costa. Striae at junction between base and cusp, diverging either side of posterior process. One or two lateral denticles on either side of cavity; lenticular to rounded in cross section. Deep triangular cavity ranging from equilateral to inequilateral. Hyaline base extends into lower part of cusp at posterior but less extensive anteriorly. Lateral denticles, posterior process and cusp albid.

Morphotype C (Fig. 4 and Pl. 3, figs 6-8): tertiopedate, similar to morphotype $B$ but with cusp inclined laterally, and denticles arranged asymmetrically either side of cavity. Costa extends entire length of posterior face of cusp to posterior process. Cusp proximally inequilateral triangular to circular with costae occasionally developed; cross section lenticular towards tip, often with one lateral face less convex than the other (Fig. 4). Posterior process with single peg-like denticle inclined slightly inwards, tip rounded if preserved entire. Two lateral denticles on outer margin much more closely spaced than those on inner margin. Denticles lenticular and bicostate in cross section, more strongly developed towards cavity margin. Cavity deep, triangular in cross section. White

\section{Explanation for Plate 4}

Figs 1-15. Coryssognathus dubius (Rhodes, 1953), all specimens from Upper Whitcliffe Formation. Figs 1-3. Sc element, PM $X$ 1245, sample 24a/2a, Prior's Frome, Hereford and Worcester (loc. 24a): Fig. 1. Lateral stereo pair, X55; Fig. 2. Detail of base showing denticles on upper and lower basal margins, X220; Fig. 3. Detail of denticles on lower basal margin, X250. Fig. 4. Sc element, lateral, PM X 1249, sample and locality as for fig. 1, X60. Fig. 5. Sc element, lateral, PM X 1240, sample and locality as for fig. 1, X65. Fig. 6. Fused simple cone elements, lateral, PM X 1206, sample 115/1, Tramway cutting, Netherton, West Midlands (loc. 20 ), X190. Figs 7, 8. Simple cone, PM X 1241, sample and locality as for fig. 1: Fig. 7. Lateral, X110; Fig. 8. Oblique view showing basal body, X220. Fig. 9. Simple cone, lateral, PM X 1227, sample 22/1, Brockhill Quarry, near Malvern Wells, Hereford and Worcester (loc. 22), X180. Figs 10, 11. Simple cone, PM X 1165, sample 8/1, Diddlebury, Corve Dale, Shropshire (loc. 8): Fig. 10. Cavity showing lamellar edges of crown tissue, X130; Fig. 11. Lateral, X75. Figs 12, 13. Simple cone, PM X 1226, sample and locality as for fig. 9: Fig. 12. Lateral, X130; Fig. 13. Detail of cavity showing lamellar edges of crown tissue and basal body, X300. Fig. 14. Simple cone, lateral, PM X 1257, sample and locality as for fig. 1, X100. Figs 15, 16. Simple cone, PM X 1231, sample and locality as for fig. 9: Fig. 15. Cavity, X250; Fig. 16. Lateral, $\mathrm{X} 110$. 


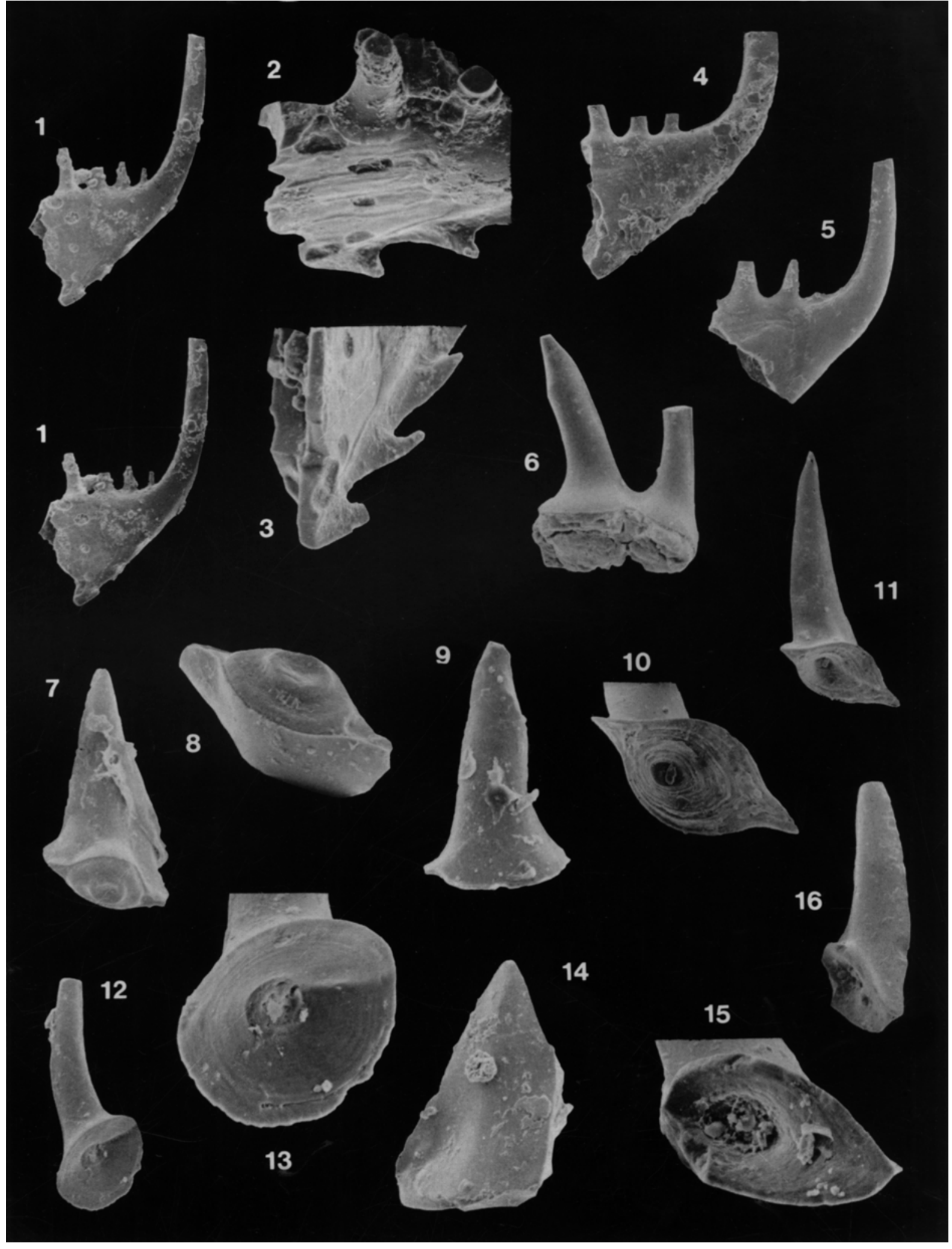




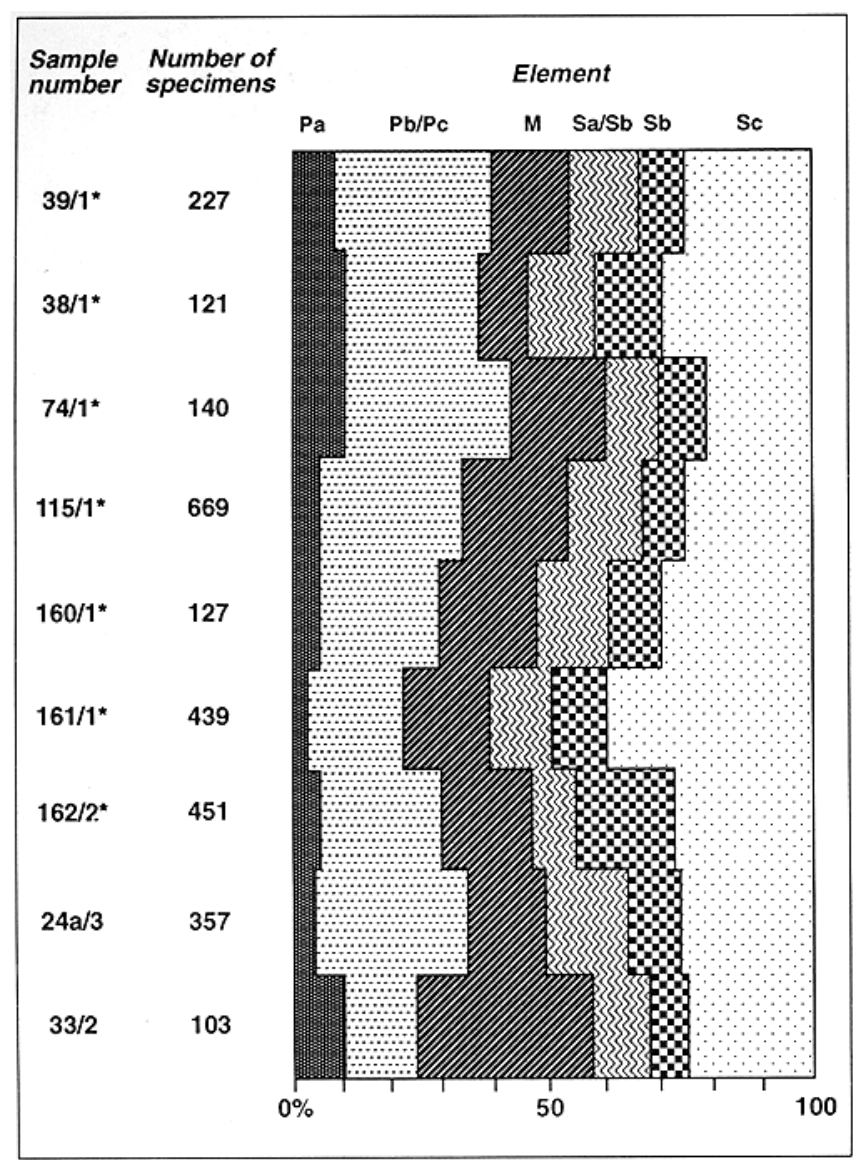

Fig. 5. Relative proportions of C. dubius elements in nine selected samples.

matter distribution as in morphotype $B$.

Sb element (Fig. 4 and P1. 3, figs 9-12): tertiopedate, distinctly asymmetrical, with inner costa extending into a downwardly directed process. Cusp twisted slightly inwards, almost ovoid at base, becoming lenticular towards apex. Inner margin flattened or weakly convex (in contrast to Sa/Sb element) and lateral margins weakly to strongly convex (Fig. 4). Uni-, bi- and tricostate forms occur, all with costa on posterior face. Posterior process with peg-like denticle curved slightly inwards. Inner lateral process with single denticle, fused to costa. Outer lateral process directed downwards and outwards with two or three sharp, discrete denticles. Cavity deep and ovoid in cross section with inner margin weakly convex, flattened or sometimes slightly concave. White matter distribution similar to $\mathrm{Sa} / \mathrm{Sb}$ elements.

Sc element (Fig. 3, Pl. 4, figs 1-5): modified dolabrate, with cusp strongly curved to posterior. Cusp bicostate, costae running entire length of anterior and posterior margins; lenticular in transverse section towards tip, proximally flattened on one lateral face and becoming weakly concave near anterior margin. Upper margin of base supports up to four peg-like denticles, with denticle closest to cavity usually most strongly developed, although all denticles may be of equal proportion. Denticles bi-costate and

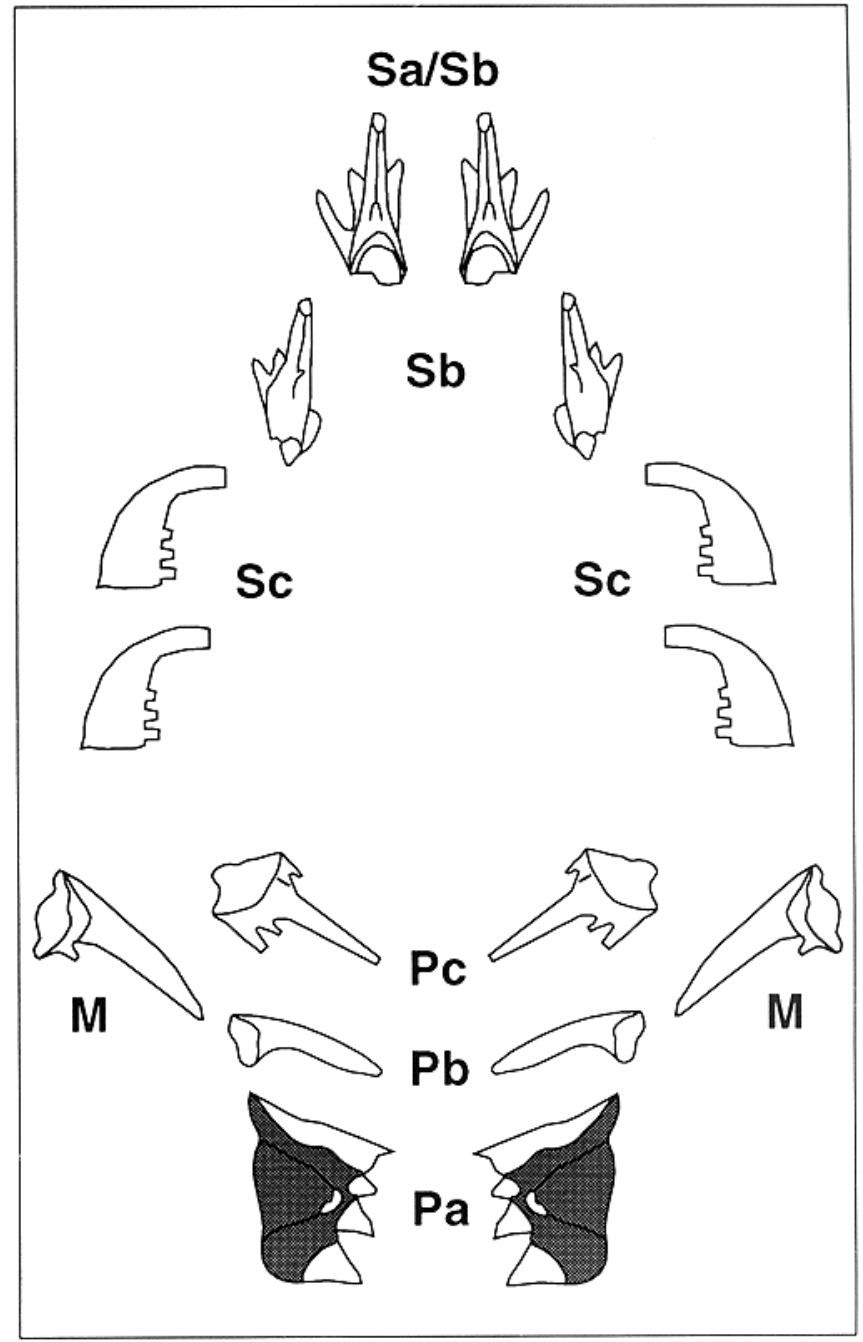

Fig. 6. Schematic reconstruction of the apparatus plan of $C$. dubius (not to scale).

lenticular in section, occasionally showing attachment sutures (Pl. 4, fig. 2). Lower margin of base sometimes with series of up to three tiny angular denticles (Pl. 4, figs 2, 3). Cavity deep, lenticular, with margin flattened on one side (Fig. 3). Area below denticles dark brown, grading into distinctive triangular amber, hyaline area at the base of the cusp (Fig. 3). White matter extends almost entire length of anterior margin but terminates at junction of cusp with base on the posterior margin producing a distinctive oblique tine across element (Fig. 3).

Coniform elements (Pl. 4, figs 6-15): small and of variable morphology, cusp slender to stubby and triangular (Pl. 4, fig. 14). Cusp proclined or erect with basal cavity circular to lenticular, commonly containing basal body (Pl. 4, fig. 8) otherwise displaying lamellar edges of crown tissue (P1. 4, figs 10, 11, 13). Rarely occur as pairs, fused at base (Pl. 4, fig. 6).

Remarks. Jeppsson (1972) and Clark et al. (1981) considered Pelekysgnathus dubius and Coryssognathus dentatus to be conspecific, while Klapper and Murphy (1974) regarded 
them as congeneric. Van den Boogaard (1990) assigned both to Coryssognathus, but distinguished $C$. dentatus by the presence of a denticulate lateral process on mature $\mathrm{Pa}$ elements. Specimens from the Upper Whitcliffe Formation show wide ontogenetic variation (Fig. 2), mature specimens having a lateral process with up to three denticles. One specimen (Pl. 1, figs 11, 12) from Aston Munslow (sample $39 / 1$ ) is almost identical to the holotype of $C$. dentatus figured by Link \& Druce (1972, pl. 2, figs 15, 18, 19), but is part of a population that contains typical C. dubius forms. The size and shape of the denticles on the posterior blade, the position of the cusp and the posteriorly facing inner lateral process suggest $C$. dentatus is conspecific with $C$. dubius. One specimen figured by Link \& Druce (1972, pl. 2, figs 13,14$)$ possesses a denticle to the anterior of the cusp, a feature not seen on any specimens from the Welsh Borderland.

The suite of elements assigned by Jeppsson $(1972,1975)$ to Distomodus dubius does not include a Pa element. The element formerly identified as Coryssognathus dentatus and Pelykysgnathus dubius has been suggested by Cooper (1974), Aldridge (1975) and van den Boogaard (1990) to be the possible Pa element for this type of apparatus. Collections from the Upper Whitcliffe Formation (Fig. 1) support this contention as the Pa element commonly occurs associated with the $D$. dubius suite but never without. All the evidence, including that from the Welsh Borderland, indicates that the names $D$. dubius and $C$. dubius are based on material from a single apparatus, and are thus synonymous.

It is common in faunas of scattered conodont elements for the Pa element to be over-represented. However, the Pa of C. dubius is always under-represented in Upper Whitcliffe faunas (Figs 1,5) and Jeppsson (1979b) noted that in Skåne, the $\mathrm{Pa}$ is restricted to a much shorter interval than the ramiforms; when present, is under-represented and of a much more juvenile growth stage. Merrill \& Powell (1980) described Pennsylvanian conodont collections that showed similar under-representation and relatively small size of $\mathrm{Pa}$ elements, and concluded that the Pa elements were less well developed than their associated ramiforms during early stages of apparatus growth. Van den Boogaard (1990) suggested that the low proportions of Pa elements in collections of Coryssognathus could similarly be explained if juvenile apparatuses had coniform elements that had not yet fused into multi-denticulate elements or if the fragile juvenile $\mathrm{Pa}$ elements suffered post-mortem breakage. From our experience of handling juvenile $C$. dubius $\mathrm{Pa}$ elements, they are easily broken. Samples from the Welsh Borderland with most coniform elements also contain relatively few $\mathrm{Pa}$ elements (Fig. 1). These large collections of coniforms include some elements morphologically similar to denticles of juvenile Pa elements of $C$. dubius (cf. Fig. 2). Juvenile Pa elements may, therefore, have been broken during deposition or laboratory processing and their dissociated denticles counted among the coniform elements.

\section{THE APPARATUS STRUCTURE OF CORYSSOGNATHUS}

To assess the apparatus composition of $C$. dubius, nine samples have been selected that each yielded more than 100 well-preserved elements with a wide size distribution. These samples are the least likely to have been affected by sorting (McGoff 1991), although all samples will have been transported to some degree in the subtidal storm depositional environment of the Upper Whitcliffe Formation. The ratio of $\mathrm{Pa}$ elements to other elements remains relatively constant (Fig. 5). Totals from all samples given in figure 1 also show similar relative proportions between elements.

Figure 5 shows a high relative frequency of $\mathrm{Pb} / \mathrm{Pc}$ elements and Sc elements in each sample. This suggests that the apparatus contained two pairs of $\mathrm{Pb} / \mathrm{Pc}$ elements, and that the $\mathrm{Pb}$ and $\mathrm{Pc}$ positions were both occupied in Coryssognathus, as in Pterospathodus, Pronognathus and Promissum (see Männik \& Aldridge, 1989; Theron et al., 1990). However, $\mathrm{Pb}$ and $\mathrm{Pc}$ elements have been counted together for the present study (Fig. 1) as abraded $\mathrm{Pb} / \mathrm{Pc}$ elements are very difficult to separate. The low numbers of $\mathrm{A}, \mathrm{B}$ and $\mathrm{C}$ morphotypes of the $\mathrm{Sa} / \mathrm{Sb}$ element (Fig. 1) suggests that they represent one morphologically plastic $\mathrm{Sa} / \mathrm{Sb}$ element varying from nearly symmetrical to twisted and somewhat asymmetrical. A similar element was identified in the Pterospathodus apparatus by Männik \& Aldridge (1989), whose $\mathrm{Sa} / \mathrm{Sb}$ designation is followed here pending further confirmation that the axial Sa position is not occupied in apparatuses of this type. The consistently high relative abundance of Sc elements (Figs 1,5) indicates that the apparatus contains two pairs of indistinguishable $\mathrm{Sc}$ elements. $\mathrm{M}$ elements are more abundant than $\mathrm{Pa}, \mathrm{Sa} / \mathrm{Sb}$, and $\mathrm{Sb}$ elements in most samples, but they are not common enough to suggest the presence of two pairs of $M$ elements in the apparatus. We therefore propose a ratio of 1:2:1:1:1:2 between $\mathrm{Pa}, \mathrm{Pb} / \mathrm{Pc}, \mathrm{M}, \mathrm{Sa} / \mathrm{Sb}, \mathrm{Sb}$ and $\mathrm{Sc}$ elements and reconstruct the apparatus of $C$. dubius as septimembrate with a total of 16 elements (Fig. 6). There is no direct evidence from bedding-plane assemblages or clusters of the relative positions of the elements in Coryssognathus, but we have followed the Promissum template in allying the $\mathrm{M}$ elements geometrically with the $P$ elements. The relative positions of the $\mathrm{P}+\mathrm{M}$ group of elements and the $S$ group are schematic, although the proximal ends of the latter do lie to the anterior in most specimens of Promissum (Theron et al., 1990; Aldridge \& Theron, 1993).

The relative numbers of coniform elements vary from sample to sample (Fig. 1). It was suggested by Jeppsson (1972) and later shown by van den Boogaard (1990) that elements of the apparatus incorporated these cones during ontogeny to become increasingly denticulate. Denticles on Pc elements each have a basal pit, incorporated by later lamellae (PI. 2, figs 9, 11) and some Sc elements show a suture between the cone-like denticle and the base of the cusp (Pl. 4, fig. 2) suggesting incorporation at a later growth stage. The cones are the right size to have been part of a multidenticulate element of the apparatus. The discrete cones, therefore, represent either denticles broken from processes of multidenticulate elements or cones not 
incorporated as denticles. It is probable that the discrete cones were attached to the parent element during life by basal tissue, and that fusion by overgrowing crown tissue occurred sequentially for more distal denticles during ontogeny.

Some other Silurian and early Devonian prioniodontid taxa appear to have possessed apparatuses similar to that of C. dubius. Early Silurian specimens described as Rotundacodina aff. $R$. dubia by Mabillard \& Aldridge (1983, pl. 4, figs 1-6) compare closely with $\mathrm{Pb}, \mathrm{Pc}$ and $\mathrm{S}$ elements of C. dubius, although no $\mathrm{Pa}$ element has as yet been recognised. The early Silurian genus Distomodus has been reconstructed with a six-element apparatus (Cooper, 1975; Barrick \& Klapper, 1976), but a seventh, erect (Pc) element is evident in material from South China (Aldridge \& Wang, unpublished collections). Similarly, Serpagli (1983) reconstructed the Icriodus woschmidti Ziegler apparatus as seximembrate, although a seventh element type is probably represented by erect specimens he illustrated as " possible e morphotypes" (Serpagli, 1983, fig. 4 G-I).

\section{ACKNOWLEDGEMENTS}

CGM wishes to acknowledge the receipt of NERC research studentship GT4 / 89 / GS / 056. We are grateful to Dr M.A. Purnell, who discussed and critically assessed the manuscript, and Mr R. Branson who provided S.E.M. and photographic assistance.

\section{Manuscript received January 1993}

Manuscript accepted August 1993

\section{REFERENCES}

Aldridge, R.J. 1975. The stratigraphic distribution of conodonts in the British Silurian. Journal of the Geological Society of London, 131, 607-618.

Aldridge, R.J. 1985. Conodonts of the Silurian System from the British Isles. In Higgins, A.C. \& Austin, R.L. (Eds), A stratigraphical index of conodonts, 68-92, 238-241, Ellis Horwood Ltd., Chichester, for British Micropalaeontological Society

Aldridge, R.J., Briggs, D.E.G., Clarkson, E.N.K. \& Smith, M.P. 1986. The affinities of conodonts - new evidence from the Carboniferous of Edinburgh, Scotland. Lethaia, 19, 279-291.

Aldridge, R.J., Briggs, D.E.G., Smith, M.P., Clarkson, E.N.K. \& Clark, N.D.L. 1993. The anatomy of conodonts. Philosophical Transactions of the Royal Society of London, B, 340, 405-421.

Aldridge, R.J. \& Smith, M.P. 1993. Conodonta. In Benton, M.J. (Ed.), The Fossil Record 2, Chapman and Hall.

Aldridge, R.J., Smith, M.P., Norby, R.D. \& Briggs, D.E.G. 1987. The architecture and function of Carboniferous polygnathacean conodont apparatuses. In Aldridge, R.J. (Ed.), Palaeobiology of conodont apparatuses, 63-75, Ellis Horwood Ltd., Chichester, for British Micropalaeontological Society.

Aldridge, R.J. \& Theron, J.N. 1993. Conodonts with preserved soft tissue from a new Upper Ordovician KonservatLagerstätte. Journal of Micropalaeontology, 12, 113-117.

Barrick, J.E. \& Klapper, G. 1976. Multielement Silurian (late Llandoverian - Wenlockian) conodonts of the Clarita
Formation, Arbuckle Mountains, Oklahoma, and phylogeny of Kockelella. Geologica et Palaeontologica, 10, 59-100.

Branson, E.B. \& Branson, C.C. 1947. Lower Silurian conodonts from Kentucky. Journal of Paleontology, 21, 549-556.

Briggs, D.E.G., Clarkson, E.N.K. \& Aldridge, R.J. 1983. The conodont animal. Lethaia, 16, 1-14.

Carls, P. \& Gandl, J. 1969. Stratigraphie und Conodonten des Unter-Devons der Östlichen Iberischen Ketten (NE-Spanien). Neues Jahrbuch für Geologie und Paläontologie Abhandlungen, 132, 155-218.

Cave, R. \& White, D.E. 1971. The exposures of Ludlow rocks and associated beds at Tite's Point and near Newnham, Gloucestershire. Geological Journal, 7, 239-254.

Clark, D.L., Sweet, W.C., Bergström, S.M., Austin, R.L., Rhodes, F.H.T., Müller, K.J., Ziegler, W., Lindström, M., Miller, J.F. \& Harris, A.G. 1981. Treatise on Invertebrate PalaeontologyConodonta. Geological Society of America \& University of Kansas miscellaneous supplement, $2 \mathbf{W}$.

Cooper, B.J. 1974. Studies of multielement Silurian conodonts. Unpublished Ph.D. thesis, Ohio State University (Columbus).

Cooper, B. J. 1975. Multielement conodonts from the Brassfield Limestone (Silurian) of Southern Ohio. Journal of Paleontology, 49, 984-1008.

Dzik, J. 1991. Evolution of oral apparatuses in the conodont chordates. Acta Palaeontologica Polonica, 36, 265-323.

Earp, J.R. 1938. The higher Silurian rocks of the Kerry district Montgomeryshire. Quarterly Journal of the Geological Society of London, 94, 1-11.

Harley, J. 1861. On the Ludlow Bone-Bed and its crustacean remains. Quarterly Journal of the Geological Society of London, $17,542-552$

Helfrich, C.T. 1974. Silurian Conodonts from the Wills Mountain Anticline, Virginia, West Virginia and Maryland. Geological Society of America Special Paper, 161.

Jeppsson, L. 1972. Some Silurian conodont apparatuses and possible conodont dimorphism. Geologica et Palaeontologica, 6, 51-69.

Jeppsson, L. 1975 [dated 1974]. Aspects of Late Silurian conodonts. Fossils \& Strata, 6, 1-54.

Jeppsson, L. 1979a. Conodont element function. Lethaia, 12, 153171.

Jeppsson, L. 1979b. Growth, element arrangement, taxonomy and ecology of selected conodonts. Publications from the Institutes of Mineralogy, Paleontology, and Quaternary Geology, University of Lund, Sweden, 218.

Jeppsson, L. \& Aldridge, R.J. 1988. Cordylodus? dubius Rhodes, 1953 (currently Distomodus? dubius; Conodonta): proposed conservation of specific name. Bulletin of Zoological Nomenclature, 45, 127-129.

Klapper, G. \& Murphy, M.A. 1974. Silurian-Lower Devonian Conodont sequence in the Roberts Mountains Formation of Central Nevada. University of California Publications in Geological Sciences, 111.

Klapper, G. \& Philip, G.M. 1972. Familial classification of reconstructed Devonian conodont apparatuses. Geologica et Palaeontologica, SB1, 97-105.

Link, A.G. \& Druce, E.C. 1972. Ludlovian and Gedinnian Conodont Stratigraphy of the Yass Basin, New South Wales. Bulletin of the Bureau of Mineral Resources, Geology and Geophysics, Australia, 134.

Mabillard, J.E. \& Aldridge, R.J. 1983. Conodonts from the 
Coralliferous Group (Silurian) of Marloes Bay, South-West Dyfed, Wales. Geologica et Palaeontologica, 17, 29-43.

Männik, P. \& Aldridge, R.J. 1989. Evolution, taxonomy and relationships of the Silurian conodont Pterospathodus. Palaeontology, 32, 893-906.

McGoff, H.J. 1991. The hydrodynamics of conodont elements. Lethaia, 24, 235-247.

Merrill, G.K. \& Powell, R.J. 1980. Palaeobiology of juvenile (nepionic?) conodonts from the Drum Limestone (Pensyllvanian, Missouri-Kansas area) and its bearing on apparatus ontogeny. Journal of Paleontology, 54, 1058-1074.

Miller, C.G. 1993. Micropalaeontology (Conodonta, Ostracoda) across the Ludlow/ Pridoli series boundary (Silurian) of Wales and the Welsh Borderland. Unpublished Ph.D. thesis, University of Leicester.

Nicoll, R.S. 1982. Multielement composition of the conodont Icriodus expansus Branson \& Mehl, from the Upper Devonian of the Canning Basin, Western Australia. Journal of Australian Geology and Geophysics, 7, 197-213.

Palmer, D.C. 1970. A stratigraphical synopsis of the Long Mountain, Montgomeryshire. Proceedings of the Geological Society of London, 1660, 341-346.

Phipps, C.B. \& Reeve, F.A.E. 1967. Stratigraphy and Geological History of the Malvern, Abberley and Ledbury Hills. Geological Journal, 5, 339-368.

Pickett, J. 1978. Silurian Conodonts from Blowclear and Liscombe Pools, New South Wales. Journal and Proceedings of the Royal Society of New South Wales, 111, 35-39.

Potter, J.F. \& Price, J.H. 1965. Comparative sections through Rocks of Ludlovian-Downtonian Age in the Llandovery and Llandeilo Districts. Proceedings of the Geologist's Association, 76, 379-402.

Rhodes, F.H.T. 1953. Some British Lower Palaeozoic conodont faunas. Philosophical Transactions of the Royal Society of London, B, 237, 261-334.

Serpagli, E. 1983. The conodont apparatus of Icriodus woschmidti woschmidti Ziegler. Fossils \& Strata, 15, 155-161.

Squirrell, H.C. and Tucker, E.V. 1960. The Geology of the Woolhope inlier. Quarterly Journal of the Geological Society of London, 116, 139-180.

Sweet, W.C. 1988. The Conodonta: Morphology, Taxonomy, Paleoecology, and Evolutionary History of a Long-Extinct Animal Phylum. Oxford University Press, New York.

Theron, J.N., Rickards, R.B. \& Aldridge, R.J. 1990. Bedding plane assemblages of Promissum pulchrum, a giant Ashgill conodont from the Table Mountain Group, South Africa. Palaeontology, 33, 577-594.

Thomas, L. 1949. Devonian-Mississippian formations of south east Iowa. Bulletin of the Geological Society of America, 60, 403438.

Uyeno, T.T. 1981 [date of imprint 1980]. Stratigraphy and conodonts of the Upper Silurian and Lower Devonian rocks in the environs of the Boothia Uplift, Canadian Arctic Archipelago. Part II Systematic study of conodonts. Bulletin of the Geological Survey of Canada, 292, 39-75.

van den Boogaard, M. 1990. A Ludlow conodont fauna from Irian Jaya (Indonesia). Scripta Geologica, 92, 1-27.

Vira, V. 1982. Late Silurian shallow and deep water conodonts from the East Baltic. In Kaljo, D.L. and Klaamann, E. (Eds), Ecostratigraphy of the East Baltic Silurian, 79-87, Academy of Sciences of the Estonian SSR Institute of Geology, Tallinn.

Walliser, O.H. \& Wang, C.-y. 1989. Upper Silurian Stratigraphy and conodonts from the Quijing District, East Yunnan, China. Courier Forschungsinstitut Senckenberg, 110, 111-121.

Walmsley, V.G. 1959. Geology of the Usk inlier (Monmouthshire). Quarterly Journal of the Geological Society of London, 114, 483-521.

Wang, C.-y. 1980. Upper Silurian conodonts from Quijing District, Yunnan [in Chinese with English summary]. Acta Palaeontologica Sinica, 19, 369-378. 